\title{
Identifikasi Patahan Menggunakan Analisis Data Deformasi Tanah di Tapak RDE Serpong
}

\section{Fault Identification Using Ground Analysis Deformation Analysis in EPR Site Serpong}

\author{
Hadi Suntoko*, Sriyana \\ Pusat Kajian Sistem Energi Nuklir-BATAN, Jl. Kuningan Barat, Mampang Prapatan, Jakarta, 12710 \\ *E-mail: hadi_suntoko@batan.go.id
}

Naskah diterima: 26 Mei 2017, direvisi: 15 Oktober 2017, disetujui: 30 November 2017

DOI: https://doi.org/10.17146/eksplorium.2017.38.2.3352

\begin{abstract}
ABSTRAK
Tapak Reaktor Daya Eksperimental (RDE) terletak di Serpong berjarak $\pm 67 \mathrm{~km}$ dari sesar aktif Cimandiri. Hasil evaluasi tapak menunjukkan bahwa tapak RDE layak dan aman dari patahan aktif. Namun, diperlukan pemantauan deformasi batuan menggunakan alat Global Positioning System (GPS). Tujuannya adalah mendapatkan koordinat teliti melalui data GPS untuk mengidentifikasi ada tidaknya aktivitas patahan dan pengaruh patahan terhadap tapak. Pemantauan menggunakan konfigurasi enam titik ukur yang memotong jalur yang diduga sebagai patahan berarah tenggara-baratlaut. Metode penelitian menggunakan pendataan koordinat titik stasiun GPS berkala BATAN dan titik stasiun GPS kontinyu BIG dalam radius $25 \mathrm{~km}$. Pengolahan data menggunakan perangkat lunak Bernese Versi 5.2 dilakukan secara radial dari titik stasiun 1 sebagai titik referensi dan dilanjutkan intepretasi data. Hasil analisis menunjukkan bahwa kondisi patahan/tektonik sekitar tapak RDE berada di kisaran 0,05 mikrostrain yang merupakan daerah dengan kondisi tektonik stabil.
\end{abstract}

Kata kunci: GPS, patahan, evaluasi tapak, deformasi

\begin{abstract}
Experimental Power Reactor (EPR) site is located in Serpong and it has a distance of $\pm 67 \mathrm{~km}$ from the Cimandiri active fault. Result of EPR site evaluation show that it is feasible and safe from the active fault. However, it is necessary to monitor the rock deformation by using Global Positioning System(GPS) tool. The goal is to obtain precise coordinates through GPS data to identify the presence of active fault activity and its impact on the site. The monitoring is using six measuring points configuration mounted crossing the southeast-northwest suppose fault line direction. The research method is using coordinate data collection from BATAN GPS periodic station and BIG GPS continuous station in radius $25 \mathrm{~km}$. Data processing is using Bernese Version 5.2 Software, proceed radially from station 1 as reference point and then continued by data interpretation. The Analysis result shows that the fault/tectonic condition near EPR site is in the range of 0.05 microstrain which is an area with stable tectonic condition.
\end{abstract}

Keywords: GPS, fault, site evaluation, deformation

\section{PENDAHULUAN}

Kawasan Puspiptek Serpong berada di bagian barat Kota Tangerang Selatan. Sesuai dengan RTRW Kota Tangerang Selatan tahun 2011-2031, kawasan Puspiptek Serpong merupakan kawasan teknologi tinggi [1] yang layak dijadikan sebagai tapak Reaktor Daya Ekperimental (RDE) berdasarkan hasil evaluasi tapak RDE 2014-2016. Hasil evaluasi tapak tersebut menyatakan bahwa 
tapak aman dari pengaruh kejadian eksternal yang berasal dari luar lokasi [2]. Kejadian eksternal yang diperkirakan dapat mempengaruhi tapak antara lain patahan aktif yang berada di bagian selatan, berjarak kurang lebih $67 \mathrm{~km}$ dari tapak.

Secara umum bahwa deformasi yang terjadi di Jawa bagian barat karena aktifitas tektonik zona subduksi di sepanjang palung Jawa dan dari sesar aktif di daratan [3]. Sesar aktif yang ada di wilayah sekitar Serpong setidaknya berjumlah tiga sesar yang telah teridentifikasi dan berada di Jawa bagian barat, yakni Sesar Cimandiri, Sesar Lembang, dan Sesar Baribis [4,5,6]. Sesar/patahan tersebut perlu diinvestigasi secara menyeluruh di sekitar tapak RDE sehingga ada atau tidaknya potensi keaktifan dan laju pergeseran sesar atau patahan yang mempengaruhi tapak dapat teridentifikasi. Beberapa peneliti menyebutkan bahwa aktivitas patahan berupa patahan geser yang memiliki arah timur laut-barat daya dan arah geseran tidak mengarah ke Serpong $[4,5,6]$ tetapi hal ini perlu diperiksa pengaruhnya dengan pemantauan di sekitar tapak RDE sesuai rekomendasi Peraturan Kepala BAPETEN Nomor 8 tahun 2013 tentang Aspek Kegempaan [7]. Pemantauan tapak dapat dilakukan menggunakan beberapa alat, salah satunya Global Positioning System (GPS). Data GPS berupa koordinat suatu titik yang memiliki akurasi tinggi, dipasang menyebar di wilayah Serpong hingga radius $25 \mathrm{~km}$. Analisis dan intepretasi data GPS menggunakan pendekatan principal strain analysis [8] diperlukan pada saat evaluasi tapak tahap pemantauan untuk mengurai dan mempelajari karakteristik kegiatan aktivitas patahan tektonik di wilayah Serpong dan sekitarnya.

Metode yang digunakan meliputi pemantauan deformasi tanah menggunakan alat GPS, pengolahan dengan perangkat lunak Bernese versi 5.2, intepretasi, analisis, dan kriteria tektonik aktif. Pendugaan adanya patahan ini diawali dari kajian kelurusan Digital Elevation Model (DEM), kemudian ditindaklanjuti dengan survei geologi permukaan [9,10]. Pemasangan alat GPS berpola lurus dan memotong jalur patahan hingga berjarak $35 \mathrm{~km}$ dari pusat kelurusan dugaan patahan sebanyak enam titik. Pendataan dilakukan secara berkala melalui pengambilan data koordinat yang dilakukan dua kali dalam setahun dan hasil pendataan kemudian dianalisis dan diintepretasi. Perka BAPETEN No 8 tahun 2013 menyatakan bahwa pada radius $5 \mathrm{~km}$ dari tapak RDE tidak boleh ada patahan kapabel [7]. Untuk melengkapi dan meyakini hasil analisis serta persiapan tahapan selanjutnya, perlu dilakukan pemantauan GPS.

Deformasi disebut juga regangan yang merupakan perubahan sifat metrik kontinyu benda dalam perpindahan dari penempatan awal menuju ke penempatan akhir. Perubahan dan pergeseran dalam sifat metrik artinya bahwa kurva tubuh material awal mengalami perubahan penempatan panjangnya ketika dipindahkan ke sebuah kurva dalam penempatan akhir [2]. Perubahan bentuk metrik memiliki tiga fenomena, yaitu perubahan linier lambat dan merayap, perubahan berkala/periodik yang merupakan perubahan selang waktu antara detik sampai tahun dan episodik yang merupakan perubahan secara tiba-tiba dan cepat.

Pemantauan menggunakan alat GPS yang ditempatkan di enam titik patok didasarkan dari penyebaran struktur geologi, yakni di Desa Bangun Bogor, Masjid Arrahman Griya Serpong Asri Desa Suradita, Kec. Cisauk, Kantor Pertanian Tangerang, alun-alun Kecamatan Pondok Aren, Stasiun Busway Daan Mogot, dan Hegar Manah yang 
dilakukan secara berkala. Stasiun kontinyu adalah stasiun milik Badan Informasi Geospasial (BIG), meliputi sembilan stasiun yang tersebar di Banten. Data GPS memberikan informasi koordinat yang kemudian arah dan pergerakan tanahnya yang kemungkinan dekat dengan dugaan patahan/sesar di sekitar tapak dianalisis dan dicatat. Pergerakan suatu sumber deformasi yang tercatat saat ini sangat penting untuk membuat model deformasi tanah untuk menjelaskan proses tektonik di Jawa bagian barat umumnya.

Tujuan dari penelitian adalah mendapatkan koordinat teliti dari pengamatan GPS untuk perhitungan laju regangan pada dugaan patahan. Besaran regangan di sekitar tapak dari analisis data GPS dapat menginformasikan kondisi tektonik terkini. Selain itu, penelitian juga bertujuan untuk memperoleh vektor kecepatan dalam rangka intepretasi keberadaan patahan kapabel di sekitar tapak RDE.

Lingkup kegiatan meliputi persiapan, pendataan, pengumpulan data, analisis, dan pelaporan. Analisis yang dihasilkan berupa regangan dari kecepatan stasiun GPS di setiap titik patok. Batasan penelitan adalah untuk mendapatkan hasil awal koordinat stasiun GPS dan vektor kecepatan stasiun GPS yang dioperasikan oleh BIG dan stasiun GPS BATAN secara berkala tahun 2015-2016. Hasil yang diperoleh dari penelitian sebelumnya menunjukkan daerah penelitian masih memiliki kondisi tektonik stabil dan diharapkan kelanjutan kegiatan pemantauan ini dapat memberikan masukan untuk tahapan lanjut pembangunan RDE [11].

\section{TEORI}

Teknologi navigasi satelit-satelit GPS dapat digunakan untuk membantu analisis patahan aktif berdasarkan perubahan posisi koordinat. Melalui pendataan stasiun-stasiun GPS dan pengukuran posisi geodesi berakurasi tinggi $(\mathrm{mm}-\mathrm{cm})$ di beberapa titik secara teratur dalam frekuensi waktu tertentu (misalnya setahun sekali) perubahan posisi koordinat bergerak dapat diketahui. Data GPS yang dikumpulkan dapat diproses untuk mengetahui arah, kecepatan tektonik (dimensi vektor), dan aktivitas yang berasal dari deformasi tanah [4].

Deformasi tanah adalah perubahan bentuk, posisi, dan dimensi dari suatu benda [12], baik merupakan bagian dari alam ataupun buatan manusia dalam skala ruang dan waktu. Berdasarkan definisi tersebut, deformasi dapat diartikan sebagai perubahan kedudukan atau pergerakan suatu titik pada benda secara absolut maupun relatif. Oleh karena itu, analisis deformasi merupakan metodologi untuk menentukan parameterparameter deformasi dengan pendekatan geodetik melalui konsep sistem koordinat [13].

\section{METODOLOGI}

Metode yang digunakan dalam penelitian ini adalah mempelajari dan mengamati pola serta kecepatan pergeseran yang terjadi pada sebuah titik ukur menggunakan alat GPS. Pola dan kecepatan pergerakan tersebut memerlukan informasi posisi yang teliti dan akurat pada titik-titik pengamatan.

Metode pengamatan GPS diawali dengan pemasangan alat, pemantauan, analisis, dan penentuan kriteria aktivitas patahan. Pemasangan alat didasarkan data geologi terutama sistem kelurusan di tapak RDE yang dipasang tegak lurus memotong sistem kelurusan. Pengolahan dan analisis yang dihasilkan dikorelasikan dengan kriteria aktivitas patahan, yakni jika nilai laju regangan >0,005 microstrain menunjukkan daerah tersebut adalah daerah tektonik aktif. 
Analisis keseluruhan menggunakan data hasil pemantauan GPS yang dipasang di enam titik stasiun berkala dan di sembilan titik stasiun kontinyu sebagai referensi hingga radius $25 \mathrm{~km}$ dari tapak RDE Serpong. Data yang terkumpul selanjutnya diolah menggunakan bantuan perangkat lunak Bernese Versi 5.2 untuk mendapatkan nilai regangan yang baik. Perhitungan nilai regangan berasal dari nilai kecepatan stasiun GPS kemudian diintepretasikan dengan menggabungkan data regangan lain. Untuk mendapatkan parameter mekanisme regangan geser dari dugaan patahan yang optimal digunakan pemodelan segitiga setiap tiga stasiun yang dikonsentrasikan pada suatu jalur survei yang melintang pada jalur patahan.

Pemantauan stasiun GPS berkala menggunakan titik patok yang dibuat sesuai standar berdasarkan kriteria BIG. Salah satu contohnya patok di perkebunan Kantor Pertanian, Kecamatan Cisauk Tangerang dan dilakukan pemantauan sebanyak dua kali dalam setahun (Gambar 1).

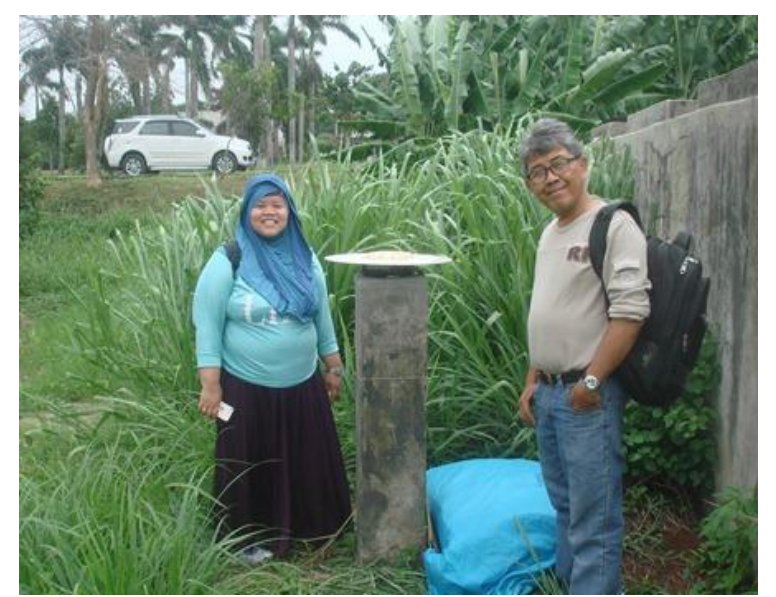

Gambar 1. Lokasi stasiun GPS di Kantor Pertanian Tangerang [2].

Data yang terkumpul dari masing masing stasiun berupa data Receiver Independent Exchange Format (RINEX) diolah menggunakan perangkat lunak. Ephemeris akhir International GNSS Service (IGS), parameter rotasi bumi, parameter model ionosfer, dan kode bias diferensial untuk satelit dan penerima diperoleh dari situs University of Bern [14]. Sementara itu, parameter perhitungan koefisien model pasang surut air laut posisi GPS dihitung berdasarkan Finite Element Solutions (FES) 2004 dari Onsala Spaca Observatory [15].

Pengolahan data digunakan untuk menghasilkan analisis terintegrasi dalam kerangka acuan International Terrestrial Reference Frame (ITRF) tahun 2008. Hal ini dilakukan secara radial dari titik stasiun 1 sebagai titik referensi untuk perhitungan dan koordinatnya ditentukan dari titik BIG sebagai titik geodetik orde-0 milik Jaring Kerangka Geodetik Nasional. Pengolahan data terdiri dari parameter-parameter deformasi yang meliputi, tegangan (stress) sebagai gaya (F) per luas permukaan (A) dan regangan (strain).

Untuk mendapatkan nilai regangan dari setiap segitiga menggunakan formula sebagai berikut:

$$
\begin{aligned}
& \left(\begin{array}{llllll}
1 & 0 & -\mathrm{L}_{1} & \mathrm{~B}_{1} & \mathrm{~L}_{1} & 0 \\
0 & 1 & \mathrm{~B}_{1} & 0 & \mathrm{~B}_{1} & \mathrm{~L}_{1} \\
1 & 0 & -\mathrm{L}_{2} & \mathrm{~B}_{2} & \mathrm{~L}_{2} & 0 \\
0 & 1 & \mathrm{~B}_{2} & 0 & \mathrm{~B}_{2} & \mathrm{~L}_{2} \\
1 & 0 & -\mathrm{L}_{3} & \mathrm{~B}_{3} & \mathrm{~L}_{3} & 0 \\
0 & 1 & \mathrm{~B}_{3} & 0 & \mathrm{~B}_{3} & \mathrm{~L}_{3}
\end{array}\right)\left(\begin{array}{l}
\mathrm{Tx} \\
\mathrm{Ty} \\
\omega \\
\varepsilon \mathrm{x} \\
\varepsilon \mathrm{xy} \\
\varepsilon \mathrm{y}
\end{array}\right)=\left(\begin{array}{l}
\mathrm{V}_{\mathrm{E} 1} \\
\mathrm{~V}_{\mathrm{N} 1} \\
\mathrm{~V}_{\mathrm{E} 2} \\
\mathrm{~V}_{\mathrm{N} 2} \\
\mathrm{~V}_{\mathrm{E} 3} \\
\mathrm{~V}_{\mathrm{N} 3}
\end{array}\right) \\
& \varepsilon_{1}=\frac{\varepsilon_{x}+\varepsilon_{y}}{2}+\sqrt{\left(\frac{\varepsilon_{x}-\varepsilon_{y}}{2}\right)^{2}+\varepsilon_{x y}^{2}}
\end{aligned}
$$

$$
\varepsilon_{2}=\frac{\varepsilon_{x}+\varepsilon_{y}}{2}-\sqrt{\left(\frac{\varepsilon_{x}-\varepsilon_{y}}{2}\right)^{2}+\varepsilon_{x y}^{2}}
$$


$\tan 2 \theta=\frac{2 \varepsilon_{x y}}{\varepsilon_{x}-\varepsilon_{y}}$

Komponen L1 = lintang stasiun GPS pertama, L2= lintang stasiun GPS kedua, L3= lintang stasiun GPS ketiga, B1= bujur stasiun GPS pertama, B2= bujur stasiun GPS kedua, B3= bujur stasiun GPS ketiga, VE1= kecepatan stasiun GPS pertama dalam komponen timurbarat, VE2 = kecepatan stasiun GPS kedua dalam komponen timur-barat, VE3= kecepatan stasiun GPS ketiga dalam komponen timur-barat, $\mathrm{VN} 1=$ kecepatan stasiun GPS pertama dalam komponen utaraselatan, VN2= kecepatan stasiun GPS kedua dalam komponen utara-selatan, dan VN3= kecepatan stasiun GPS ketiga dalam komponen utara-selatan; Tx $=$ translasi titik pusat segitiga dalam komponen timur-barat; Ty = translasi titik pusat segitiga dalam komponen utara-selatan; $\omega=$ rotasi titik pusat segitiga; $\quad E x=$ regangan normal dalam komponen timur-barat; $\quad \epsilon y=$ regangan normal. Visualisasi regangan beserta komponen-komponen regangan dapat dilihat pada Gambar 2.

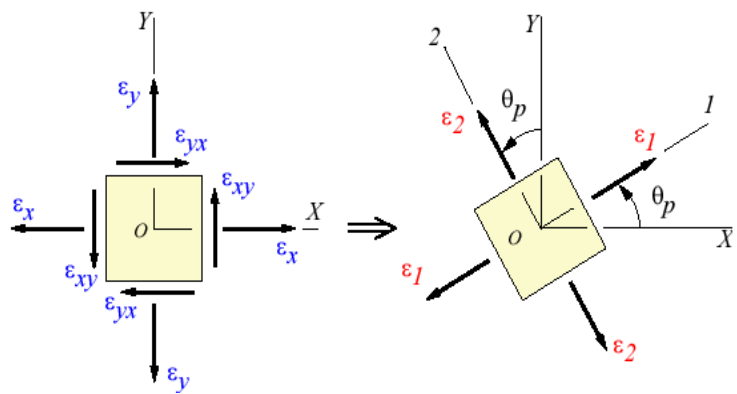

Gambar 2. Visualisasi komponen regangan yang digunakan dalam penelitian [8]

Secara umum metode yang digunakan untuk mendapatkan regangan dari kecepatan stasiun GPS adalah dengan membuat jaring segitiga setiap tiga stasiun GPS (Gambar 3). Jumlah segitiga yang terbentuk, yaitu 14 segitiga. Titik hitam menunjukkan lokasi stasiun GPS kontinyu yang dioperasikan oleh BIG.

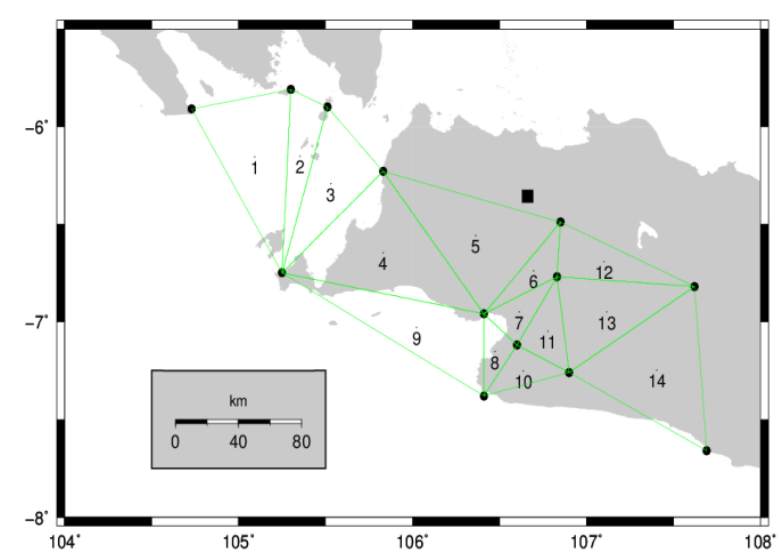

Gambar 3. Jaring segitiga yang terbentuk untuk perhitungan regangan [2].

\section{HASIL DAN PEMBAHASAN}

Data hasil pengamatan GPS diolah menggunakan metode diferensial dengan motoda jaring. Titik GPS yang terpasang di enam lokasi stasiun pemantauan hingga radius $25 \mathrm{~km}$ merupakan lokasi titik yang didasarkan data geologi berupa kelurusankelurusan yang diduga sebagai patahan berarah tenggara-barat laut [16]. Titik-titik diikatkan dengan titik bantu yang ada di Serpong dalam suatu jaring kerangka dasar. Pengukuran dilakukan dua kali dalam satu tahun untuk mengetahui perubahan koordinat detail dari pengamatan GPS berkala milik BATAN dan pengukuran dari GPS kontinyu milik BIG yang berada di sekitar stasiunstasiun GPS milik BATAN. Keterangan lokasi stasiun GPS berkala dapat dilihat pada Tabel 1.

Data yang diperoleh merupakan hasil pendataan GPS berkala milik BATAN periode pengamatan dari pertengahan tahun 2014 hingga 2016. Stasiun pengamatan tersebut membentang dari utara ke selatan memotong jalur dugaan patahan dalam radius $25 \mathrm{~km}$ (berarah tenggara-barat laut). Lokasi 
enam titik pengamatan GPS, yakni di Desa Bangun Jaya Bogor, Masjid Arrahman Komplek Griya Serpong Cisauk, Kantor Pertanian Tangerang, alun alun Kecamatan Pondok Aren, Stasiun busway Daan Mogot, dan Hegar Manah. Model titik pengamatan koordinat berupa patok ukur telah disesuaikan dengan stasiun BIG sebagai acuan, termasuk dalam pengambilan data juga merujuk standar acuan baik dari Fakultas Geodesi Institut Teknologi Bandung (ITB) maupun tenaga ahli dari Pusat Jaring Kontrol Geodesi dan Geodinamika-BIG. Lokasi titik pengamatan GPS berkala dan sebaran stasiun kontinyu dapat dilihat pada Gambar 4.
Tabel 1. Lokasi stasiun berkala milik BATAN.

\begin{tabular}{cl}
\hline Nama Stasiun & \multicolumn{1}{c}{ Lokasi } \\
\hline C001 & $\begin{array}{l}\text { Halaman Desa Bunar Kecamatan } \\
\text { Bangun Jaya Bogor }\end{array}$ \\
& Halaman Masjid Arrahman \\
& Komplek Griya Serpong Asri \\
& Desa Suradita Kec. Cisauk Tg \\
& Area Kantor Pertanian Desa \\
& Sampora Kecamatan Cisauk \\
& Tangerang \\
& Alun alun Kecamatan Pondok \\
C004 & Aren Desa Parigi Baru Tangerang \\
& Pool Busway Daan Mogot Pesing \\
C005 & Jakarta Barat \\
& Kampung Hegarmanah \\
J010 & Kecamatan Cigudeg Bogor \\
&
\end{tabular}

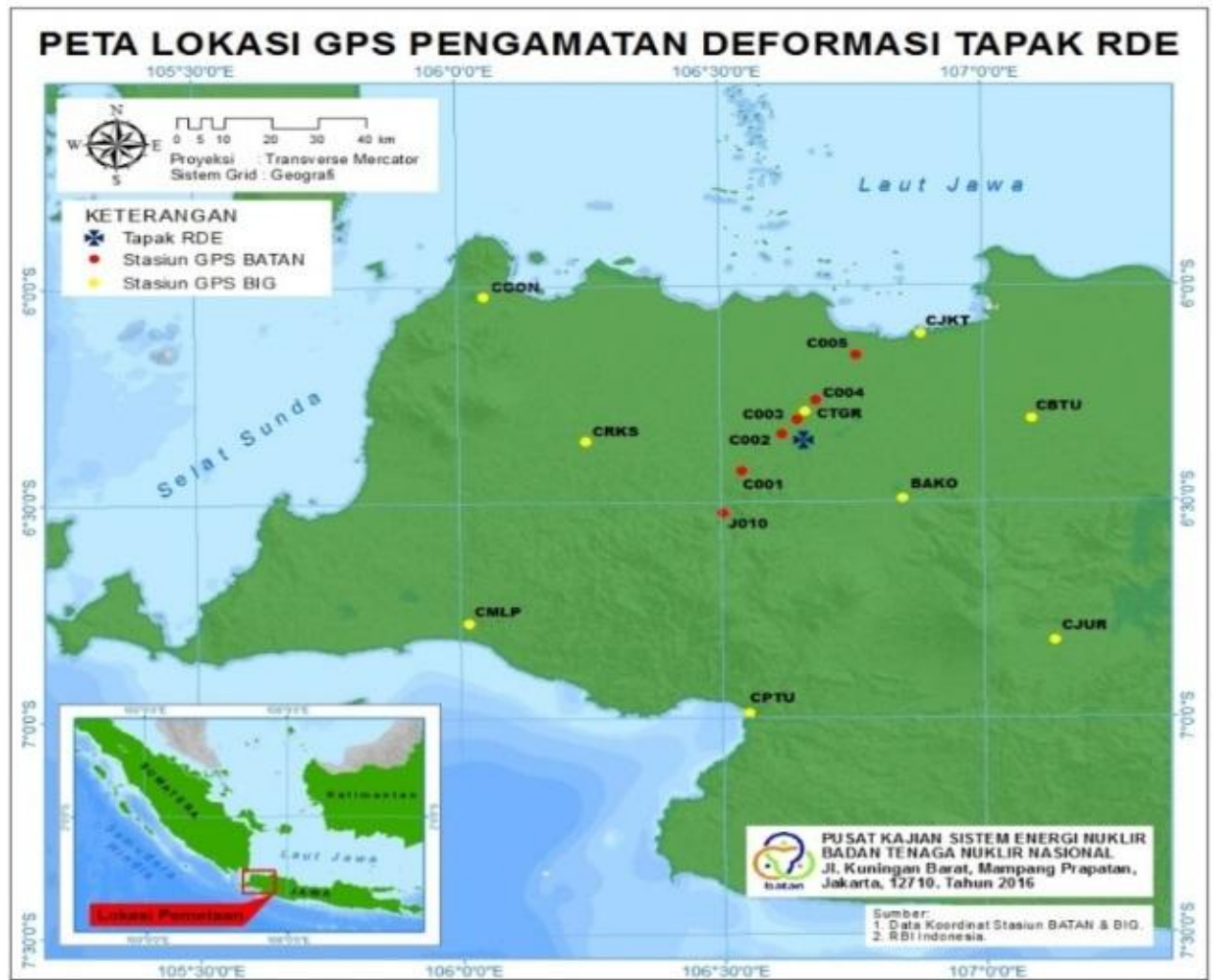

Gambar 4. Titik stasiun GPS berkala (merah) dan kontinyu (kuning), serta dugaan patahan (biru) [2].

Pin biru yang terlihat di dalam peta tersebut menunjukkan lokasi tapak RDE, pin kuning menunjukkan stasiun kontinyu milik BIG, pin merah adalah stasiun GPS berkala milik BATAN, dan garis putus-putus warna biru adalah arah patahan yang berarah barat laut-tenggara. Dari hasil pengamatan GPS geodetik tahun 2016 kemudian dibandingkan dengan pengamatan tahun 2015 terlihat bahwa vektor pergeseran titik-titik pengamatan GPS geodetik secara dominan mengarah ke tenggara sesuai tren pergeseran 
Pulau Jawa. Ada titik yang memberikan arah vektor tidak searah, kemungkinan disebabkan tingkat akurasi yang berbeda pada saat pengukuran data.

Hasil pengolahan dan perhitungan awal berdasarkan dari kecepatan tanah (deformasi) diperoleh berdasarkan analisis data GPS kontinyu dan berkala. Pengolahan tersebut menunjukkan nilai vektor kecepatan dalam
ITRF yang didominasi oleh data kecepatan stasiun GPS kontinyu milik BIG. Hasil pengolahan berupa koordinat teliti di stasiun GPS berkala meliputi enam stasiun dengan kode C001, C002, C003, C004, C005, dan J010. Stasiun GPS milik BIG terdiri dari sembilan stasiun dengan kode CJUR, CBTU, CJKT, BAKO, CTGR, CPTU, CRKS, CGON, CMLP (Tabel 2).

Tabel 2. Nilai koordinat stasiun GPS beserta kecepatannya dalam ITRF 2008 [14,15].

\begin{tabular}{ccccccc}
\hline $\begin{array}{c}\text { Nama } \\
\text { Stasiun }\end{array}$ & $\begin{array}{c}\text { Lintang } \\
(\mathbf{o})\end{array}$ & $\begin{array}{c}\text { Bujur } \\
(\mathbf{o})\end{array}$ & $\begin{array}{c}\mathbf{E} \\
(\mathbf{m m})\end{array}$ & $\begin{array}{c}\mathbf{N} \\
(\mathbf{m m})\end{array}$ & $\begin{array}{c}\mathbf{s d E} \\
(\mathbf{m m})\end{array}$ & $\begin{array}{c}\mathbf{s d N} \\
(\mathbf{m m})\end{array}$ \\
\hline CJUR & $-6,8221$ & 107,1381 & 16,54 & $-15,26$ & 5,96 & 4,44 \\
CBTU & $-6,3083$ & 107,0964 & 21,47 & $-17,14$ & 2,80 & 2,08 \\
CJKT & $-6,1101$ & 106,8845 & 19,91 & $-19,89$ & 2,84 & 2,20 \\
BAKO & $-6,4911$ & 106,8489 & 22,66 & $-18,02$ & 2,93 & 2,14 \\
C005 & $-6,1590$ & 106,7659 & 21,69 & $-17,87$ & 10,31 & 8,50 \\
C004 & $-6,2743$ & 106,6930 & 27,13 & $-21,93$ & 7,56 & 5,96 \\
CTGR & $-6,2908$ & 106,6638 & 18,24 & $-16,06$ & 3,26 & 2,52 \\
C003 & $-6,3077$ & 106,6369 & 24,96 & $-12,09$ & 8,47 & 6,86 \\
C002 & $-6,3526$ & 106,6319 & 34,24 & $-26,48$ & 6,50 & 5,07 \\
CPTU & $-6,9892$ & 106,5514 & 21,65 & $-11,19$ & 4,20 & 3,01 \\
C001 & $-6,4390$ & 106,5202 & 22,12 & $-8,35$ & 8,36 & 7,07 \\
J010 & $-6,5260$ & 106,5064 & $-21,17$ & $-6,28$ & 9,57 & 8,10 \\
CRKS & $-6,3579$ & 106,2463 & 23,09 & $-15,41$ & 4,00 & 3,41 \\
CGON & $-6,0208$ & 106,0523 & 22,42 & $-17,83$ & 2,85 & 2,18 \\
CMLP & $-6,7783$ & 106,0191 & 12,91 & $-9,12$ & 4,22 & 3,18 \\
\hline
\end{tabular}

Beberapa arah vektor kecepatan dominan ke arah tenggara namun satu vektor memperlihatkan arah barat daya. Hal ini diintepretasikan sebagai akibat dari pendataan terhadap posisi titik ukur dan bukan akibat adanya tektonik lokal. Arah vektor (tanda panah warna merah) menunjukkan arah yang hampir sama bahwa semua stasiun GPS memberikan arah menuju ke tenggara sesuai arah Pulau Jawa dalam skala regional (Gambar 5).

Arah pergerakan tersebut sesuai dengan pergerakan Pulau Jawa sekarang [17]. Secara umum analisis terhadap pergerakan didominasi arah tenggara yang merupakan gambaran kondisi deformasi terkini. Hasil pengolahan data dan analisis regangan yang didasarkan dari pemantauan stasiun GPS berkala milik BATAN dan stasiun GPS kontinyu milik BIG dapat dilihat di Tabel 3.

Nilai setiap komponen regangan tersebut menunjukkan nilai dari segitiga yang terbentuk dengan menghubungkan tiga stasiun GPS kontinyu beserta visualisasinya. Komponen regangan terhitung dibagi menjadi dua waktu, yaitu regangan 1 dan regangan 2 . Bila kedua regangan tersebut dibandingkan, maka akan memiliki perbedaan yang tidak signifikan di setiap lokasi penelitian. Regangan 1 mempunyai nilai tertinggi 0,09 dan 0,013 mikrostrain, sementara itu nilai regangan 2 tertinggi -0,009 mikrostrain. 


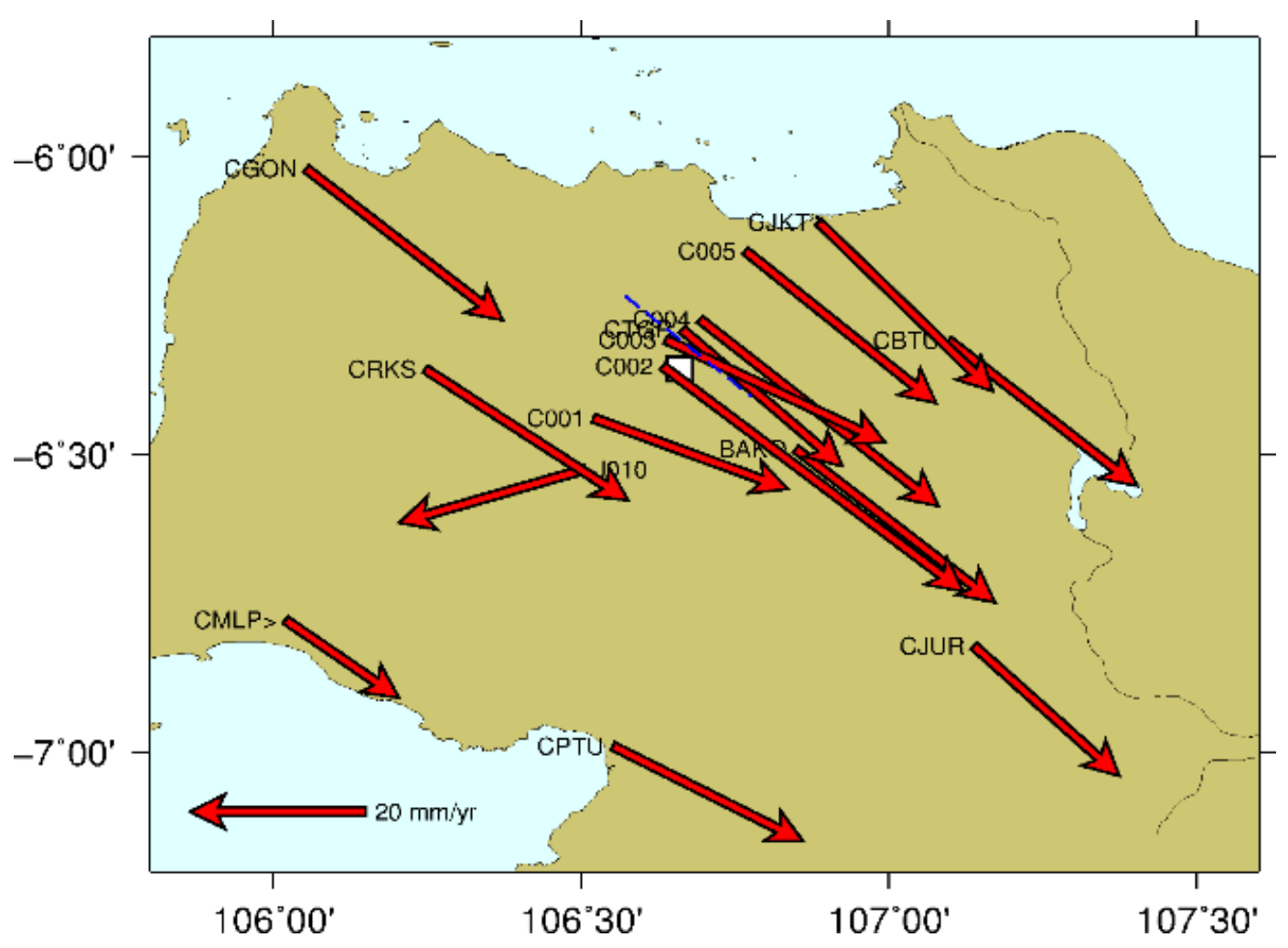

Gambar 5. Arah vektor dari GPS dalam ITRF 2008 [2].

Tabel 3. Nilai setiap komponen regangan dari setiap segitiga yang dibentuk [2].

\begin{tabular}{cccccc}
\hline $\begin{array}{c}\text { Nomor } \\
\text { Segitiga }\end{array}$ & $\begin{array}{c}\text { Bujur } \\
\text { Sentroid } \\
(\mathbf{o})\end{array}$ & $\begin{array}{c}\text { Lintang } \\
\text { Sentroid } \\
(\mathbf{o})\end{array}$ & $\begin{array}{c}\text { Komponen } \\
\text { Regangan 1 } \\
\text { (mikrostrain) }\end{array}$ & $\begin{array}{c}\text { Komponen } \\
\text { Regangan 2 } \\
\text { (mikrostrain) }\end{array}$ & $\begin{array}{c}\text { Sudut Teta } \\
(\mathbf{o})\end{array}$ \\
\hline 1 & 105,093 & $-6,157$ & 0,013 & $-0,009$ & $-30,522$ \\
2 & 105,353 & $-6,153$ & 0,014 & $-0,005$ & $-16,877$ \\
3 & 105,530 & $-6,293$ & $-0,001$ & $-0,007$ & 16,436 \\
4 & 105,830 & $-6,647$ & 0,005 & $-0,003$ & $-35,996$ \\
5 & 106,363 & $-6,560$ & 0,005 & $-0,007$ & $-39,480$ \\
6 & 106,697 & $-6,740$ & 0,009 & $-0,007$ & $-37,267$ \\
7 & 106,613 & $-6,950$ & 0,005 & $-0,004$ & $-45,430$ \\
8 & 106,473 & $-7,153$ & 0,005 & $-0,004$ & $-36,665$ \\
9 & 106,023 & $-7,030$ & 0,004 & $-0,002$ & $-20,469$ \\
10 & 106,637 & $-7,253$ & 0,005 & $-0,005$ & $-28,036$ \\
11 & 106,777 & $-7,050$ & 0,005 & $-0,004$ & $-36,497$ \\
12 & 107,100 & $-6,693$ & 0,005 & $-0,007$ & $-43,530$ \\
13 & 107,117 & $-6,950$ & 0,003 & $-0,004$ & $-45,624$ \\
14 & 107,403 & $-7,247$ & 0,007 & $-0,005$ & $-78,175$ \\
\hline
\end{tabular}


Regangan di daerah tapak berada pada kisaran 0,001-0,009 mikrostrain. Sementara itu, tektonik stabil blok Sundaland berada di angka 0,005 mikrostrain [3]. Mengacu kepada referensi tersebut, daerah tapak merupakan daerah yang mempunyai kondisi tektonik yang relatif stabil. Tindak lanjut untuk mendapatkan analisis regangan secara komprehensif dengan kesalahan yang minimal menggunakan pemantauan stasiun GPS di daerah penelitian.

\section{KESIMPULAN}

Berdasarkan analisis data GPS koordinat teliti yang berasal dari stasiun pemantauan tanah menunjukkan nilai regangan deformasi tanah berkisar 0,001-0,009 mikrostrain. Hasil tersebut memberikan informasi bahwa daerah penelitian mempunyai kondisi tektonik yang relatif stabil (lebih rendah dari 0,005 mikrostrain). Arah vektor kecepatan menunjukkan arah relatif menuju tenggara dan sesuai pergerakan Pulau Jawa secara regional. Pengukuran GPS berkala masih berlangsung hingga beberapa tahun untuk mendapatkan hasil yang lebih baik.

\section{UCAPAN TERIMA KASIH}

Dengan ini penulis mengucapkan terimakasih kepada semua pihak terutama PKSEN-BATAN yang telah memberikan izin, kawan-kawan Bidang KDT-PKSEN yang membantu dalam kegiatan analisis, serta tim Geodesi ITB, yaitu Bapak Melano, Bapak Irwan, dan Bapak Endro.

\section{DAFTAR PUSTAKA}

[1] Pemda Tangerang Selatan, Peraturan Daerah Kota Tangerang Selatan No. 15 Tahun 2011 tentang Rencana Tata Ruang Wilayah Kota Tangerang Selatan Tahun 2011-2031. Tangerang Selatan, 2011.

[2] BATAN, "Laporan Evaluasi Tapak Reaktor Daya Eksperimental Kawasan Puspitek Serpong," Jakarta, 2015.
[3] Y. Bock, L. Prawirodirdjo, J. F. Genrich, C. W. Stevens, R. McCaffrey, C. Subarya, S. S. . Puntodewo, and E. Calais, "Crustal Motion in Indonesia from Global Positioning System Measurements," J. Geophys. Res., vol. 108, no. B8, p. 2367, 2003.

[4] I. Meilano, H. Z. Abidin, H. Andreas, I. Gumilar, D. Sarsito, R. Hanifa, Rino, H. Harjono, T. Kato, F. Kimata, and Y. Fukuda, "Slip Rate Estimation of the Lembang Fault West Java from Geodetic Observation," J. Disaster Res., vol. 7, no. 1, pp. 12-18, 2012.

[5] H. Suntoko and S. Supartoyo, "Konfirmasi Patahan Permukaan Berdasarkan Data Geologi Dan Data Gempa Daerah Kawasan Puspiptek Serpong," J. Pengemb. Energi Nukl., vol. 18, no. 1, pp. 1-10, 2016.

[6] E. P. Sari and H. Subakti, "Identification of Baribis fault - West Java using second vertical derivative method of gravity," in AIP Conf. Proc. 1658, 2015.

[7] BAPETEN, Perka BAPETEN No. 8 Tahun 2013 tentang Evaluasi Tapak Aspek Kegempaan untuk Industri Nuklir. Jakarta, 2013.

[8] Efunda, "Principal Directions, Principal Strain," 2015. [Online]. Available: http://www.efunda.com/formulae/solid_mechanic s/mat_mechanics/plane_strain_principal.cfm.

[9] International Atomic Energy Agency (IAEA), Safety Standards Series No. NS-R-3 Site Evaluation for Nuclear Installations, vol. 3. 2003.

[10] A. Jarvis, H.I., A. Reuter, A. Nelson, and E. Guevara, "Hole-filled SRTM for the globe Version 4, available from the CGIAR-CSI SRTM 90m Database," CGIAR CSI Consort. Spat. Inf., no. January, pp. 1-9, 2016.

[11] Marjiyono, H. Suntoko, A. Soehaimi, Yuliastuti, and H. Syaeful, "Kelas Soil Daerah Sekitar Rencana Tapak Reaktor Daya Eksperimental (RDE) Serpong Dari Data Mikrotremor," J. Pengemb. Energi Nukl., vol. 17, no. 1, pp. 57-66, 2015.

[12] S. Kuang, Geodetic Network Analysis and Optimal Design: Concepts and Applications. Chelsea, Michigan: Ann Arbor Pr Inc, 1996.

[13] N. R. Hanifa, T. Sagiya, F. Kimata, J. Efendi, H. Z. Abidin, and I. Meilano, "Interplate coupling model off the southwestern coast of Java, Indonesia, based on continuous GPS data in 2008-2010," Earth Planet. Sci. Lett., vol. 401, pp. 159-171, 2014.

[14] University of Bern, "CODE - Analysis Center," 2017. [Online]. Available: http://www.aiub.unibe.ch/research/code__analys is_center/index_eng.html.

[15] Onsala Space Observatory, "The free ocean tide loading provider," 2017. [Online]. Available: http://holt.oso.chalmers.se/loading/index.html.

[16] T. Turkandi, Sidarto, D. A. Agustyanto, and M. 
M. Hadiwidjojo, "Peta Geologi Lembar Jakarta dan kepulauan Seribu, Jawa," Bandung, 1992.

[17] J. F. Genrich, Y. Bock, R. McCaffrey, L. Prawirodirdjo, C. W. Stevens, S. S. . Puntodewo, C. Subarya, and S. Wdowinsky, "Distribution of Slip at the Northern Sumatran Fault System," J.
Geophys. Res., vol. 105, no. B12, pp. 2832728341, 2000. 